\title{
Transformational Leadership, Organizational Justice and Organizational Citizenship Behavior
}

\author{
Dönüştürücü Liderlik, Örgütsel Adalet ve Örgütsel Vatandaşlık Davranışı
}

Lütfi SÜRÜCÜ ${ }^{1}$

\begin{abstract}
Purpose: The study aims to examine the relationship between transformational leadership, organizational justice, and organizational citizenship behavior in the context of Social Exchange Theory.

Design/Methodology: A questionnaire study was conducted face-toface survey with 315 participants, who were selected by convenience sampling method, which is one of the non-random methods in the study. The data were analyzed by SPSS and AMOS programs.

Findings: As a result of the analysis; It has been determined that transformational leadership and organizational justice have a significant and positive effect on organizational citizenship behavior. Also, it is concluded that organizational justice has a mediating role in the effect of transformational leadership on organizational citizenship behavior.

Limitations: Obtaining the sample from 2 textile factory workers in Istanbul and the cross-sectional design of the research are important limitations.

Originality/Value: Having examined the literature, it is seen that there are limited studies on determining the critical factors that mediate the relationship between transformational leadership and organizational citizenship behavior. While the findings of the study help us to understand the antecedent of organizational citizenship behavior more deeply, attracting the attention of the practitioners constitutes the original value of the study.
\end{abstract}

Keywords: Transformational Leadership, Organizational Justice, Organizational Citizenship Behavior
Öz

Amaç: Bu araştırmanın amacı, dönüştürücü liderlik, örgütsel adalet ve örgütsel vatandaşlık davranışı arasındaki ilişkinin sosyal değişim teorisi bağlamında incelenmesidir.

Tasarım/Yöntem: Araştırmada tesadüfi olmayan yöntemlerden kolayda örneklem yoluyla belirlenen 315 katılımcı ile yüz yüze anket yapılmıştır. Elde edilen veriler SPSS ve AMOS programları ile analiz edilmiştir.

Bulgular: Analizler sonucunda; dönüştürücü lider ve örgütsel adaletin örgütsel vatandaşlık davranıșı üzerinde anlamlı ve pozitif bir etkisinin olduğu tespit edilmiştir. Bu bulguya ilave olarak, dönüștürücü liderin örgütsel vatandaşlık davranışına etkisinde örgütsel adaletin aracı rolü olduğu sonucuna ulaşılmıştır.

Sınırılıklar: Örneklemin İstanbul'da faaliyet gösteren 2 tekstil fabrikası çalışanlarından elde edilmesi ve araştırmanın kesitsel tasarımı önemli sinırlılıklardır.

Özgünlük/Değer: Alanyazın incelendiğinde, dönüşümcü liderlik ile örgütsel vatandaşlık davranışı arasındaki ilişkiye aracilık eden kritik faktörlerin belirlenmesine yönelik sınırlı sayıda calıșma olduğu görülmektedir. Araştırmada elde edilen bulgular örgütsel vatandaşlık davranışıını öncüllerini daha derinden anlamamıza yardımcı olurken uygulayıcıların da dikkatini çekecek nitelikte olması araştırmanın özgün değerini oluşturmaktadır.

Anahtar Kelimeler: Dönüştürücü Liderlik, Örgütsel Adalet, Örgütsel Vatandaşlık Davranışı 


\section{INTRODUCTION}

In today's dynamic and competitive business environment, the extra-role behaviors of employees beyond the duties specified in their job descriptions have become very important for organizational success. An employee's optional extra-role behaviors, in other words, performing beyond job descriptions, are defined as organizational citizenship behavior. It is possible to define organizational citizenship behavior as behaviors performed voluntarily by employees to increase the efficiency of the organization and not clearly recognized by the official reward system (Khaola \& Rambe, 2020). Organizational citizenship behavior is a voluntary behavior pattern that supports organizational functions by respecting the well-being of other employees within the organization (Basalamah \& Ardana, 2020). In this respect, organizational citizenship behavior includes voluntary participation in organizational activities and performance that exceeds the normal duties in job descriptions (McShane \& Glinow, 2015; Khaola \& Rambe, 2020).

Organizational citizenship behavior contributes significantly to organizations gaining sustainable competitive advantage, especially in environments where competition is fierce. Also, the organizational citizenship behavior of the employees is closely related to high customer satisfaction, organizational commitment, and low turnover rate (Podsakoff et al., 2009). As a result, research into the antecedents of organizational citizenship behavior is important, and it is useful to investigate the factors that impact organizational citizenship behavior (Nurjanah et al., 2020).

In research on the antecedents of organizational citizenship behavior, leadership style (Lee et al., 2018; Tian et al., 2020; Zhang et al., 2020), organizational justice (Majeed et., 2018), job satisfaction (Khaskheli et al., 2020) and organizational commitment (Nurjanah et al., 2020) have been documented to increase organizational citizenship behavior. As Khaola and Rambe (2020) stated, one of the most discussed issues in the researches on antecedents of organizational citizenship behavior is the implementation of an effective leadership style. Different leadership styles have been discussed in the literature and many new leadership styles have been proposed since 2000. However, the overlap between the suggested leadership style is extremely problematic and there is probably "concept repetition" (Sürücü \& Sağbaş, 2021). It is thought that it is only the scope of the concept of leadership and the way it is perceived. For this reason, the transformational leadership style, which is one of the most effective examples of contemporary leadership theories, has been examined in the research.

As stated in a meta-analysis study, transformational leadership is an effective and widely used leadership style (Wang et al., 2011). Bass (1990) states that the transformational leadership is a leadership style that instils trust, admiration, and loyalty in its employees. A transformational leader has behaviors that inspire employees to perform more than expected, motivate them, and put aside the personal interests of employees to benefit the organization (Nurjanah et al., 2020). Given that the transformational leader positively affects employee behavior, it is clear that the transformational leader has the potential to improve organizational citizenship behavior. However, the findings on the relationship between transformational leaders and organizational citizenship behavior are somewhat blurred. In the literature, findings are indicating that the transformational leader positively influences organizational citizenship behavior (Lee et al., 2018; Khaola \& Rambe, 2020), as well as unrelated findings (Kent \& Chelladurai, 2001; Kim, 2014). The reason for the different findings may be due to the mediators that underlie the transformational leadershiporganizational citizenship behavior relationship, as several researchers have pointed out (Khaola $\&$ Rambe, 2020). However, there has been insufficient research to determine the critical factors that mediate this relationship (Lee et al., 2018). Previous studies document that organizational culture (Kim, 2014), employee job satisfaction (Nurjanah et al., 2020), emotional commitment (Lee et al., 2018) and psychological capital (Nandan \& Azim, 2015) have mediating effects in this relationship. Despite the studies, a recent meta-analysis study calls for more research on the psychological mechanisms underlying the relationship between transformational leadership and organizational citizenship behavior (Nohe \& Hertel, 2017). Also, research on the transformational leaders and potential outcomes has been criticized for examining the mediating effect without relying on a clear theory (Nohe \& Hertel, 2017; Van Knippenberg \& Sitkin, 2013). Using the theory of Social Exchange as a theoretical framework, this study responds to calls and criticisms. Based on the gap in 
the literature, the mediating role of organizational justice in the effect of transformational leadership on organizational citizenship behavior was investigated. The research is considered to attract the attention of practitioners as well as expand the organizational citizenship literature.

\section{LITERATURE REVIEW}

\subsection{Transformational Leadership and Organizational Citizenship Behavior}

Today's employees prefer self-sacrificing leaders who avoid abuse of power, act as role models for them, and work for employee well-being (Su et al., 2019; Tian et al., 2020). Therefore, managers in any position within the organization are expected to display leadership behaviors (Hall et al., 2015). A leader is an important function of management, helping to maximize efficiency and achieve organizational goals.

In the last thirty years, transformational leadership has been one of the most prominent leadership approaches to understanding individual, group and organizational effectiveness. (Zhang et al., 2020). Transformational leadership conceptualized by Bass (1990) includes "idealized influence, inspirational motivation, intellectual stimulation, and individualized consideration" behaviors. Idealized influence refers to the degree to which leaders exhibit behaviors that will enable their followers to identify with them. Inspirational motivation refers to the degree to which leaders can convey their vision in ways that inspire their employees. Intellectual stimulation refers to the degree to which employees demand different opinions and the leader can question the current practices of the organization. Individualized consideration refers to the degree to which employees act as mentors to meet their needs.

Transformational leaders focus on real-time problems and shape their behavior by motivating employees to achieve organizational goals effectively. They encourage their employees to participate in organizational activities and help them in all activities and coach them. They communicate their broad vision to their employees, giving them goals and expanding their vision. Also, paying attention to the personal development of the employees strives for the employees to exhibit high performance by increasing their qualifications (Tian et al., 2020; Y1k1lmaz, 2020). Transformational leadership increases the self-confidence of the employees throughout all the activities they have done and ensure them to feel self-confident. Malik et al. (2016) state that the transformational leader internally motivates employees to perform beyond their job descriptions, as they act by employee's values. These positive attitudes of transformational leader towards their employees may lead to an increase in organizational citizenship behavior in employees (Wisnawa \& Dewi, 2020).

Social Exchange Theory is probably one of the most influential theories for explaining the general dynamics that lead to the emergence of organizational citizenship behavior. Also, The theory provides a framework for understanding why the transformational leadership can be associated with organizational citizenship behavior (Nohe \& Hertel, 2017). Blau (1964) states in his seminal study that social exchange relations are characterized by trust and loyalty and develop based on the norm of reciprocity between the parties (leader-employee). From this point of view, employees will engage in social exchange in response to the positive behaviors of transformational leaders for them and will respond to positive behaviors of transformational leaders by demonstrating organizational citizenship behaviors. Having considered in the context of Social Exchange Theory, the transformational leadership is an important driving force that increases the extra-role behavior of employees to perform beyond their responsibilities (Permatasari et al., 2017). In recent studies supporting the theory of social exchange, it has been documented that the transformational leadership positively affects organizational citizenship behavior (Nurjanah et al., 2020; Tian et al., 2020; Zhang et al., 2020; Y1k1lmaz, 2020; Wisnawa \& Dewi, 2020). The following hypothesis has been developed to be tested in line with the theory of Social Exchange and related researches.

Hypothesis 1: Transformational leadership affects organizational citizenship behavior significantly and positively.

\subsection{Organizational Justice and Organizational Citizenship Behavior}

Employee concerns about the distribution of organizational resources such as wages, rewards, and recognition are known as distributive justice. Procedural justice expresses that employees are 
concerned about the fairness of the procedures and criteria used to distribute these resources. Finally, the employee's perceptions of fair treatment by organizational leaders and decision-makers express interactional justice. As a group; Distributive, procedural, and interactional justices have been accepted by Greenberg (1987) as "Organizational Justice", a term first used to refer to people's perceptions of justice in organizations (Erkutlu, 2011). Fassina et al. (2008) state that it will be appropriate considering the shared variances between different types of justice in studies on the relationship between justice and $\mathrm{OCB}$, it is more accurate to investigate the perception of justice as a whole rather than investigating the effects of distributive, procedural, and interactional justice separately on organizational citizenship behavior. For this reason, the perception of justice was examined as a whole concept in the study.

Organizational justice perception is assumed to create open-ended social exchange relationships, and such relationships lead to the employee's repayment obligation to the leader or organization. Social Exchange Theory predicts that if the perception of organizational justice is high, the employee will also need to respond through organizational citizenship behavior (Spector \& Che, 2014). Having considered the formation process of organizational citizenship behavior from the perspective of the employee, factors such as fair treatment and organizational justice are among the important elements that require a social exchange. As a matter of fact, Nandan and Azim (2015) state that employees will respond to social exchange by increasing their organizational citizenship behaviors when they feel that managers are treated fairly. In other words, if the exchanges are considered fair, the employees will most likely act in a way that benefits the organization (organizational citizenship behavior) by performing justice mutually. In the opposite case, when employees believe that the organization or leaders are not treating them fairly, employees will believe that social exchange is violated. In such a case, employees will be more likely to respond to injustice by exhibiting low performance, increased absenteeism, reduced emotional attachment, or less civic behavior.

In addition to the theory of Social Exchange, Organ (1990) proposed a theoretical basis for the relationship between organizational justice and organizational citizenship behavior using "Equity Theory". The theory accepts organizational citizenship behavior as a job input and states that the employee who perceives the job rewards as fair according to the inputs of the job will continue the organizational citizenship behavior, and the employee who perceives it as excess will react to the underpayment by increasing the organizational citizenship behavior.

Having considered in the context of Social Exchange and Equity Theory, the perception of organizational justice among employees may positively affect organizational citizenship behavior. In studies conducted to support the literature, a significant relationship was found between organizational justice and organizational citizenship behavior (Bellini et al., 2019; Saifi \& Shahzad, 2017; Majeed et al., 2018). The following hypothesis has been developed to be investigated in line with the researches and existing theories.

Hypothesis 2: Organizational justice affects organizational citizenship behavior significantly and positively.

\subsection{The Mediating Role of Organizational Justice}

Transformational leaders support their employees in achieving a common vision and goals and create inspiring motivation in their employees by guiding their business life (Afsar \& Umrani, 2019). In this respect, the transformational leader is expected to positively affect organizational citizenship behavior. According to the Social Exchange Theory, in the case of mutual exchange obligations between two or more parties, the parties take conditional actions. Based on the Theory, it can be thought that typical employees may engage in positive behaviors such as organizational citizenship behavior (OCB) that can benefit the leader and the organization in return for the benefits the transformational leader (TL) has shown to them. Empirical studies conducted in this direction document that TL positively affects OCB (Khaola \& Rambe, 2020; Tian et al., 2020; Zhang et al., 2020)

Although the relationship between TL and OCB has been empirically confirmed, there has been little interest in researching the social and psychological mechanisms by which the transformational leader affects organizational citizenship behavior (Ng, 2017; Khaola \& Rambe, 
2020). Podsakoff et al. (2000) stated that the total effect of the transformational leadership on organizational citizenship behavior is not direct but indirect. It is thought that investigating such mechanisms will be more enlightening in understanding how and why the transformational leader has a positive effect on employees $(\mathrm{Ng}, 2017)$.

There is theoretical evidence in the literature that the transformational leadership indirectly influences organizational citizenship behavior through organizational justice. $\mathrm{Ng}$ (2017) states that an effective leader will create a feeling that employees are appreciated by the organization, and in return, employees will participate in organizational citizenship behaviors in a way that will increase the efficiency of the organization. Similarly, Khaola and Rambe (2020) emphasize that the transformational leadership increases the perception of justice among employees and that will result in organizational commitment and organizational citizenship behavior. Majeed et al. (2018) stated that the relationship of employees with organizational citizenship behavior depends on some antecedents and one of the antecedents is the perception of organizational justice. Current literature shows that employees 'attitudes and behaviors are influenced by the perception of organizational justice and that concerns about justice affect employees' working lives in various ways (Iqbal et al., 2012; Shin \& Sohn, 2015).

A leader is the source of justice within the organization as the representative of the organization. The organizational justice created by the leader has a positive effect on the attitudes and behaviors of the employees, and it is assumed that the employees will create a sense of trust towards the leader (Khaola \& Rambe, 2020). Organizational justice is not only recognized as one of the premises of organizational citizenship behavior but also sometimes considered a proxy for social exchange. With the leaders treating their employees fairly and the employees using the organizational citizenship behavior as an exchange resource, change occurs and organizational citizenship behavior will increase within the organization. In summary, as the leader's behavior and organizational justice are theoretically based on the theory of Social Exchange, justice mediates the relationships between the transformational leadership and employee attitudes and behaviors. The following hypothesis has been proposed based on the arguments stated above.

Hypothesis 3: Organizational Justice has a mediating role in the relationship between transformational leadership and organizational citizenship behaviors

\section{METHOD}

\subsection{Research Model}

In the study, a conceptual model including the transformational leader, organizational citizenship behavior, and organizational justice is proposed. The proposed research model is shown in Figure 1.

Figure 1: Research Model

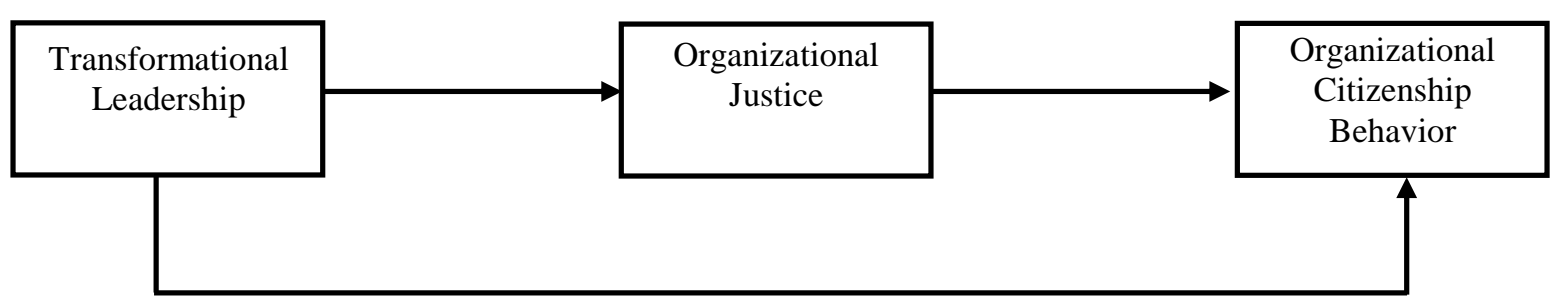

\subsection{Population and Sample}

Textile workers constitute the population of the study. No technique was applied in the selection of samples in the study. The research data were obtained from the employees of 2 textile factories in Istanbul using the convenience sampling method. These factories are preferred because they have permitted the study. First of all, factory managers were interviewed and permission was asked for research. After obtaining the necessary permissions from the managers, the ethics committee permission was obtained from the Head of the Ethics Committee of the Leadership University (Ethics Committee Nu: ALU-ETK-2021-02). To carry out the research, 3 personnel who trained about conducting questionnaires were sent to the relevant factories, and an on-site questionnaire was applied 
at rest hours. The questionnaires were delivered in sealed envelopes to prevent bias while responding to the statements in the questionnaire and they were asked to fill in an environment where there were no managers/supervisors. 411 of the 700 questionnaires prepared were distributed to the participants. No response was provided for 40 questionnaires. The collected 371 questionnaires were examined by the researcher and 56 questionnaires that were not filled inappropriately were not included in the study. As a result, the research hypotheses were tested with 315 valid survey data.

$42.54 \%$ of the participants are women and $57.46 \%$ are men. While $34.60 \%$ are single, $65.40 \%$ are married. $19.37 \%$ of the participants are in primary education, $33.01 \%$ high school, $26.03 \%$ associate degree, and $21.59 \%$ university graduates. $42.86 \%$ of the participants are in the age group 25 and under, $26.35 \%$ are in the $26-30$ age group, $23.49 \%$ are in the $31-40$ age group, $7.30 \%$ are in the age group of 41 and over. $60.95 \%$ of these participants are 5 years or less, $26.35 \%$ are $6-10$ years, $8.57 \%$ are $11-15$ years, $4.13 \%$ are 16 years and more works in place.

\subsection{Measures}

In the study, Measures developed previously and used frequently in recent studies were preferred.

Transformational Leadership: A 7-item scale developed by Carless et al. (2000) was used to determine the perception of transformational leadership in participants. The adaptation of the scale to Turkish, its validity and reliability study was conducted by Naktiyok (2015). The scale prepared in 5points Likert type expresses " $1=$ Strongly Disagree to $5=$ Strongly Agree Sample questions of the scale; "My leader promotes cooperation by establishing an atmosphere of trust." and "My leader supports the development of employees".

Organizational Citizenship Behavior: A 12-item scale developed by DiPaola and Hoy (2005) was used to measure organizational citizenship behavior in participants. The adaptation of the scale to Turkish, its validity and reliability study were carried out by Taştan and Yılmaz (2010). The scale prepared in 5-points Likert type expresses " $1=$ Strongly Disagree to $5=$ Strongly Agree". Sample questions belonging to a single dimension scale; "I share my knowledge on various issues", "I make innovative suggestions to increase the quality in the workplace." in the form.

Organizational Justice: A 20-item scale developed by Colquitt (2001) was used to determine the participants' perceptions of organizational justice. The adaptation to Turkish, validity and reliability study of the scale made by Özmen et al. (2007) includes $1=$ A little to $5=$ Mostly. Sample questions of the scale are as follows: "Does it value you?", "Does it lead you unfair comments and criticism?".

\section{FINDINGS}

The structural validity and reliability of the scales were primarily examined in the study. Analysis results are shown in Table 1.

Table 1: Validity and Reliability Results

\begin{tabular}{lccc}
\hline Variables & Cronbach Alfa & Composite Reliability & Factor Loadings \\
\hline Transformational Leader & 0,798 & 0,831 & $0,510-0,802$ \\
\hline Organizational Citizenship Behavior & 0,868 & 0,909 & $0,514-0,844$ \\
\hline Organizational Justice & 0,893 & 0,901 & $0,625-0,891$ \\
\hline
\end{tabular}

In the analyzes, it was determined that the factor loadings of the transformational leadership scale were between 0.510 and 0.802 , and the Cronbach's Alpha value, which indicates the internal consistency, was 0.798 , and the composite reliability value was 0.831 . The factor loadings of the organizational citizenship behavior scale were measured as 0.514-0.844, the Cronbach Alpha value as 0.868 , and the composite reliability value as 0.909 . The factor loadings of the organizational justice scale, which is the last scale used in the study, are 0.625-0.891, Cronbach Alpha value is 0.893, and the composite reliability value is 0.901 . These values are 0.7 and above, which is generally accepted in the literature for the reliability of the scale (Sürücü \& Maslakç1, 2020). The findings show that the scales used in the research are reliable. The factor loadings of the scales are 0.5 and above. Factor loadings of 0.5 and above indicate that the expressions in the scales have good factor loadings (Sürücü 
\& Maslakç1, 2020). Finally, the fit indexes of the research model were checked and the model was found to have good fit indices $(\mathrm{CMIN} / \mathrm{DF}=2.995, \mathrm{GFI}=0.923, \mathrm{RFI}=0.943, \mathrm{TLI}=0.952, \mathrm{CFI}=$ 0.961 , RMSEA $=0.051$ ).

It is recommended to control the distribution of data in determining statistical methods in the literature (Sürücü \& Maslakç1, 2020). In this context, the distribution of the responses of the participants to the relevant scales was checked. Hair et al. (2014) states that if kurtosis and skewness values are between -1.5 and +1.5 , the data show a normal distribution. The values obtained as a result of the analysis (Table 2) show that the data have a normal distribution.

The results of the correlation analysis performed to determine the strength and direction of the relationship between variables are shown in Table 2 .

Table 2: Correlation Analysis Results

\begin{tabular}{lccccc}
\hline Variables & Mean & S.d. & $\mathbf{1 .}$ & $\mathbf{2 .}$ & $\mathbf{3 .}$ \\
\hline 1. Transformational Leader & 3,658 & 0,808 & 1 & & \\
\hline 2. Organizational Citizenship Behavior & 3,975 & 0,702 & $0,476^{* *}$ & 1 & 1 \\
\hline 3. Organizational Justice & 3,336 & 0,859 & $0,508^{* *}$ & $0,413^{* *}$ & $-0,343$ \\
\hline Skewness & & & $-0,577$ & 0,040 & $-0,089$ \\
\hline Kurtosis & & & 0,291 & 1,061 & \\
\hline
\end{tabular}

Table 2 shows that the transformational leader has a positive correlation with organizational citizenship behavior $(r=0.476, p<0.05)$ and organizational justice $(r=0.508, p<0.05)$. Also, there is a positive correlation between organizational justice and organizational citizenship behavior $(\mathrm{r}=$ $0.413, \mathrm{p}<0.05)$. Having examined the correlation values, it is seen that the correlation between variables is moderate.

To test the hypotheses, Process Macro Model 4, developed by Hayes (2017), was used as an add-on to the SPSS program. The results of the analysis performed with 5000 resampling numbers at a 95\% confidence interval are shown in Table 3.

Table 3: Regression Results

\begin{tabular}{|c|c|c|c|c|c|}
\hline Regression Path & Effect & SE & $\mathbf{t}$ & LLCI & ULCI \\
\hline Transformational Leader $\rightarrow$ OCB & 0,136 & 0,429 & 3,109 & 0,0491 & 0,2179 \\
\hline Transformational Leader $\rightarrow$ Organizational Justice & 0,540 & 0,542 & 11,944 & 0,4513 & 0,6292 \\
\hline Organizational Justice $\rightarrow$ OCB & 0,255 & 0,457 & 5,580 & 0,1650 & 0,3446 \\
\hline Indirect Effect $(\mathrm{TL} \rightarrow \mathrm{OJ} \rightarrow \mathrm{OCB})$ & 0,721 & 0,260 & - & 0,0214 & 0,1247 \\
\hline
\end{tabular}

In the analysis results, transformational leader had a significant and positive effect with organizational citizenship behavior $(\beta=0.136,95 \% \mathrm{CI}=[0.0491,0.2179], \mathrm{t}=3.109, \mathrm{p}<0.05)$ and organizational justice perception $(\beta=0.540,95 \% \mathrm{CI}=[0.4513,0.6292], \mathrm{t}=11.944, \mathrm{p}<0.05)$. In addition to these findings, the perception of organizational justice has also been found to have a significant and positive effect on organizational citizenship behavior $(\beta=0.255,95 \% \mathrm{CI}=[0.1650$, $0.3446], \mathrm{t}=5.580, \mathrm{p}<0.05$ ). Hayes (2017) states that the lower and upper limits (LLCI, ULCI) are controlled to check the significance of the obtained regression coefficients and the regression coefficients are significant when these values do not contain zero (0). When Table 3 is examined, it is seen that the lower and upper limits do not include zero. In line with these findings, Hypothesis 1 and Hypothesis 2 in the study were supported.

Finally, in the research, it was suggested that organizational justice has a mediating role in the relationship between transformational leadership and organizational citizenship behavior (Hypothesis 3 ). To determine the mediating role of organizational justice, the indirect effect of the transformational leadership on organizational citizenship behavior was examined and the effect was found to be significant $(\beta=0.721, \mathrm{SH}=0.260,95 \% \mathrm{BCA} \mathrm{CI}=[0.0214,0.1247])$. Hypothesis 3 , which is the last hypothesis of the research, was supported in line with the findings obtained.

\section{DISCUSSION}

Although there are studies on the effect of transformational leadership on organizational citizenship behavior, studies on determining the critical factors that mediate the relationship between 
the two variables are not sufficient (Lee et al., 2018). Also, calls are made to further investigate the psychological mechanisms underlying the relationship between the TL and OCB (Nohe \& Hertel, 2017; $\mathrm{Ng}, 2017)$. This research is trying to close the gap in the literature and answer the calls made. The main findings of the study are presented below.

In the study, it was determined that TL had a significant and positive effect on OCB. In fact, this is an expected result, because transformational leaders create a supportive work environment by treating their employees with respect and fairness. This environment created encourages employees to show extra-role behaviors (such as organizational citizenship behavior) for the success of the organization, by ensuring that employees have positive feelings towards their organization. In addition, transformational leaders take care of their employees, taking into account the individual needs of the employees. In addition, They provide an inspiring motivation for employees to achieve common vision and goals. From the perspective of Social Exchange Theory, employees respond to the positive behaviors of the transformational leader by increasing their organizational citizenship behavior because of the close attention of the transformational leaders. The findings of the study can be considered reasonable in line with the current literature and Social Exchange Theory. Also This finding of the study is in line with the results obtained in previous studies (Nurjanah et al., 2020; Wisnawa \& Dewi, 2020).

Another finding obtained in the study is that organizational justice affects organizational citizenship behavior in employees significantly and positively. This finding of the study shows that employee behavior is affected by the perception of organizational justice and that concerns about justice are reflected in various aspects of the employee's work life. If the employees believe that the organization's decisions are fair, there will be a sense of trust in their leader. Increasing mutual trust between leader and employee improves social exchange relations. Employees who believe they are benefited by their leaders often feel obliged to 'pay for the good'. In this case, the employee responds by demonstrating organizational citizenship behaviors that will benefit the leader and organization. The findings of the study are a continuation of the previous research results (Bellini et al., 2019; Saifi \& Shahzad, 2017; Majeed et al., 2018).

Finally, it was determined in the study that organizational justice mediates the relationship between TL and OCB. This is the most important finding of the study and its contribution to the literature that organizational justice has a mediating effect on the relationship between TL and OCB is important in terms of providing information to practitioners who aim to increase OCB within the organization. As stated in previous chapters, leaders as representatives of organizations are responsible for ensuring justice in organizations. Indeed, Van Knippenberg et al. (2007) states that leaders are important resources in the formation of justice and injustice within the organization. Consistent with this argument, it can be said that the positive behavior of the transformational leader and their approach towards their employees will create a fair environment within the organization. In response to the perception of justice that occurs within the organization, employees also respond by actively adhering to their organization, which ultimately prompts employees to participate in organizational citizenship behavior. Also, considering that employee behavior is based on the relationship of social exchange, the employee's behavior within the organization is shaped by the employee's perception of justice and the prevalence of organizational justice. The transformational leaders who provide justice in the organization make the employees feel that they are important to the organization, and this motivates the employees to act that benefits the organization. Supporting the literature, Khaola and Rambe (2020) state that employees evaluate whether the leader is acting fairly before participating in organizational citizenship behavior and that organizational justice is the antecedent for the transformational leadership to positively affect the behavior of organizational citizenship. Research findings show that TL positively affects the employees 'perception of organizational justice and that the perception of justice increases the employees' orientation towards organizational citizenship behaviors.

The previous studies have documented that organizational culture, job satisfaction, emotional commitment, and psychological capital have a mediating effect on the relationship between TL - OCB. The study expands the previous studies on the determination of mediating effect and shows that one of 
the psychological mechanisms underlying the relationship between TL and OCB is organizational justice. In this aspect, the research extends previous studies.

\subsection{Managerial Implications}

In the study, it was determined that managers' performance of transformational leadership style increases organizational citizenship behavior, which is critical for organizational efficiency, and organizational justice has an intermediary role in this relationship. This finding provides insights into how managers can strategically increase organizational citizenship behavior in their employees. Managers should clearly explain their visions to their employees and create a collaborative work environment, as the transformational leader does, to increase extra-role behaviors in their employees. This created environment unites groups within the organization in line with a common goal, allowing them to show extra-role behaviors for the success of the organization. Moreover, if managers are careful in the process of assignment of jobs and the implementation of reward systems, the perception of organizational justice in their employees will improve positively. The high perception of organizational justice will indirectly increase the organizational citizenship behavior in employees.

Barling et al. (1996) documented in their study that transformational leadership qualities can be developed with education and can be improved later. For this reason, it is recommended that human resources managers design training to bring transformational leadership qualities to all managers in the organization. As a continuation of past research findings, this study emphasizes the importance of organizational justice perception. Providing employees with a perception of justice is one of the main duties of the leader. Therefore, leaders at all stages must treat their employees fairly.

\subsection{Limitations}

Some limitations should not be overlooked when evaluating the results of the study. The cross-sectional design of the study fails to explain how TL affects organizational citizenship behavior. Also, considering that the research data are collected from one sector (textile workers), it is not sufficient to generalize. For this reason, obtaining data from different sectors and collecting data at certain time intervals can eliminate the limitations of the research. Finally, to discover the psychological mechanisms underlying the relationship between TL and OCB; Variables such as positive psychological capital, psychological well-being, and commitment can be investigated as mediators or regulatory variables in this relationship.

Ethics Statement: Permission for this study was obtained from the Ethics Committee of Leadership University with the decision number dated 12/01/2021 and numbered ALU-ETK-2021-02 of the relevant board. In case of detection of a contrary situation, AKAD Journal has no responsibility and all responsibility belongs to the author of the study.

Etik Beyan: Bu çalışmada kullanılan anket yöntemi için Liderlik Üniversitesi Etik Kurulu'ndan 12/01/2021 tarihli ve ALU-ETK-2021-02 sıra sayll karart ile izin alınmıştır. Aksi bir durumun tespiti halinde AKAD Dergisinin hiçbir sorumluluğu olmayıp, tüm sorumluluk çalışmanın yazarına aittir.

\section{REFERENCES}

Afsar, B., \& Umrani, W. A. (2019). Transformational leadership and innovative work behavior: The role of motivation to learn, task complexity and innovation climate. European Journal of Innovation Management, 23(3), 402-428. https://doi.org/10.1108/EJIM-12-2018-0257

Barling, J., Weber, T., \& Kelloway, E. K. (1996). Effects of transformational leadership training on attitudinal and financial outcomes: A field experiment. Journal of Applied Psychology, 81(6), 827-838. https://doi.org/10.1037/0021-9010.81.6.827

Basalamah, C. S. B. S., \& Ardana, I. K. (2020). Organizational commitment in mediating the influence of transformational leadership on organizational citizenship behavior. American Journal of Humanities and Social Sciences Research, 4(2), 434-440. https://www.ajhssr.com/wp-content/uploads/2020/12/ZX20412434440.pdf 
Bass, B. M. (1990). From transactional to transformational leadership: Learning to share the vision. Organizational Dynamics, 1(18), 19-32. http://phd.meghan-smith.com/wp content/uploads/2016/01/Bass-B..pdf

Bellini, D., Ramaci, T., Bonaiuto, M., Cubico, S., Favretto, G., \& Johnsen, S. Å. K. (2019). Exploring the influence of working environments' restorative quality on organisational citizenship behaviours. International Journal of Environment, Workplace and Employment, 5(1), 32-50. https://doi.org/10.1504/IJEWE.2019.097146

Blau, P. M. (1964). Exchange and power in social life. John Wiley \& Sons.

Carless, S. A., Wearing, A. J., \& Mann, L. (2000). A short measure of transformational leadership. Journal of Business and Psychology, 14(3), 389-405. https://doi.org/10.1023/A:1022991115523

Colquitt, J. A. (2001). On the dimensionality of organizational justice: A construct validation of a measure. Journal of Applied Psychology, 86(3), 386-400. https://doi.org/10.1037//0021$\underline{9010.86 .3 .386}$

DiPaola, M. F., \& Hoy, W. K. (2005). Organizational citizenship of faculty and achievement of high school students. The High School Journal, 88(3), 35-44. https://muse.jhu.edu/article/178380/summary

Erkutlu, H. (2011). The moderating role of organizational culture in the relationship between organizational justice and organizational citizenship behaviors. Leadership \& Organization Development Journal, 32(6), 532-554. https://doi.org/10.1108/01437731111161058

Fassina, N. E., Jones, D. A., \& Uggerslev, K. L. (2008). Meta-analytic tests of relationships between organizational justice and citizenship behavior: Testing agent-system and shared-variance models. Journal of Organizational Behavior, 29(6), 805-828. https://doi.org/10.1002/job.494

Greenberg, J. (1987). A taxonomy of organizational justice theories. Academy of Management Review, 12(1), 9-22. https://doi.org/10.5465/amr.1987.4306437

Hair, J., Hult, G. T. M., Ringle, C., \& Sarstedt, M. (2014). A primer on partial least squares structural equation modeling (PLS-SEM). Thousands Oaks, Sage.

Hall, J., Johnson, S., Wysocki, A., Kepner, K., Farnsworth, D., \& Clark, J. (2015). Transformational leadership: The transformation of managers and associates (HRO2O). University of Florida.

Hayes, A. F. (2017). Introduction to mediation, moderation, and conditional process analysis: A regression-based approach. Guilford publications.

Iqbal, H. K., Aziz, U., \& Tasawar, A. (2012). Impact of organizational justice on organizational citizenship behavior: An empirical evidence from Pakistan. World Applied Sciences Journal, 19(9), 1348-1354. https://doi.org/10.5829/idosi.wasj.2012.19.09.750

Kent, A., \& Chelladurai, P. (2001). Perceived transformational leadership, organizational commitment, and citizenship behavior: A case study in intercollegiate athletics. Journal of Sport Management, 15(2), 135-159. https://doi.org/10.1123/jsm.15.2.135

Khaola, P., \& Rambe, P. (2020). The effects of transformational leadership on organisational citizenship behaviour: The role of organisational justice and affective commitment. Management Research Review, 44(3), 381-398. https://doi.org/10.1108/MRR-07$\underline{2019-0323}$

Khaskheli, A., Jiang, Y., Raza, S. A., Qureshi, M. A., Khan, K. A., \& Salam, J. (2020). Do CSR activities increase organizational citizenship behavior among employees? Mediating role of affective commitment and job satisfaction. Corporate Social Responsibility and Environmental Management, 27(6), 2941-2955. https://doi.org/10.1002/csr.2013

Kim, H. (2014). Transformational leadership, organizational clan culture, organizational affective commitment, and organizational citizenship behavior: A case of South Korea's public sector. Public Organization Review, 14(3), 397-417. https://doi.org/10.1007/s11115-013-0225-z 
Lee, Y. H., Woo, B., \& Kim, Y. (2018). Transformational leadership and organizational citizenship behavior: Mediating role of affective commitment. International Journal of Sports Science \& Coaching, 13(3), 373-382. https://doi.org/10.1177/1747954117725286

Majeed, S., Mufti, S., \& Jan, M. (2018). Organizational justice as a predictor of organizational citizenship behavior: An empirical study. AGU International Journal of Research in Social Sciences \& Humanities, 6(1), 9-14. https://www.researchgate.net/profile/ShayistaMajeed/publication/329539041 Organizational Justice as a Predictor of Organizational Citi zenship Behavior An Empirical Study/links/5c0e80c94585157ac1b84b11/OrganizationalJustice-as-a-Predictor-of-Organizational-Citizenship-Behavior-An-Empirical-Study.pdf

Malik, S. Z., Saleem, M., \& Naeem, R. (2016). Effect of leadership styles on organizational citizenship behaviour in employees of telecom sector in Pakistan. Pakistan Economic and Social Review, 54(2), 385-406. https://www.jstor.org/stable/26616714

McShane, S., Olekalns, M., Newman, A., \& Travaglione, T. (2015). Organisational behaviour 5e; emerging knowledge. Global insights. McGraw-Hill Education Australia.

Naktiyok, S. (2015). Dönüşürü̈ü liderlik ve örgütsel desteğin örgütsel bağlllı ve işten ayrılma niyetine etkisi: Örgütsel güven algısının aracı rolü (Yayın No: 429700) [Doktora Tezi, Atatürk Üniversitesi] Yüksek Öğretim Kurumu Tez Merkezi. https://tez.yok.gov.tr/UlusalTezMerkezi/tezSorguSonucYeni.jsp

Nandan, T., \& Azim, A. M. M. (2015). Organizational justice and organizational citizenship behavior: Mediating role of psychological capital. American International Journal of Social Science, 4(6), 148-156. http://www.aijssnet.com/journals/Vol_4_No_6_December_2015/19.pdf

Ng, T. W. (2017). Transformational leadership and performance outcomes: Analyses of multiple mediation pathways. The Leadership Quarterly, 28(3), 385-417. https://doi.org/10.1016/j.leaqua.2016.11.008

Nohe, C., \& Hertel, G. (2017). Transformational leadership and organizational citizenship behavior: A meta-analytic test of underlying mechanisms. Frontiers in Psychology, 1(8), 1364-1378. https://doi.org/10.3389/fpsyg.2017.01364

Nurjanah, S., Pebianti, V., \& Handaru, A. W. (2020). The influence of transformational leadership, job satisfaction, and organizational commitments on organizational citizenship behavior (OCB) in the inspectorate general of the ministry of education and culture. Cogent Business \& Management, 7(1), 1793521. https://doi.org/10.1080/23311975.2020.1793521

Organ, D. W. (1990). The motivational basis of organizational citizenship behavior. In B. M. Staw, \& L. L. Cummings (Eds.), Research in organizational behavior (pp.43-72), JAI Press.

Özmen, Ö. N., Arbak, Y., \& Özer, P. S. (2007). Adalete verilen değerin adalet algıları üzerindeki etkisinin sorgulanmasına ilișkin bir araștırma. Ege Akademik Bakış, 7(1), 17-33. https://dergipark.org.tr/tr/download/article-file/556986

Permatasari, D. V., Ghalib, S., \& Irwansyah, I. (2017). The influence of transformational leadership on organizational citizenship behavior (OCB) and organizational commitment through employee job satisfaction of PT. Panin Bank, Tbk Banjarbaru. Journal of Business and Development, 6(1), 36-42. https://ppjp.ulm.ac.id/journal/index.php/bisnispembangunan/article/viewFile/2768/2414

Podsakoff, N. P., Whiting, S. W., Podsakoff, P. M., \& Blume, B. D. (2009). Individual-and organizational-level consequences of organizational citizenship behaviors: A meta-analysis. Journal Apply Psychology, 1(94), 122-141. https://doi.org/10.1037/a0013079

Podsakoff, P. M., MacKenzie, S. B., Paine, J. B., \& Bachrach, D. G. (2000). Organizational citizenship behaviors: A critical review of the theoretical and empirical literature and suggestions for future research. Journal of Management, 26(3), 513-563. https://doi.org/10.1016/S0149-2063(00)00047-7 
Saifi, I. A., \& Shahzad, K. (2017). The mediating role of job satisfaction in the relationship between organizational justice and organizational citizenship behavior. Pakistan Journal of Commerce and Social Sciences (PJCSS), 11(1), 126-146. http://www.jespk.net/publications/362.pdf

Shin, J., \& Sohn, Y. W. (2015). Effects of employees' social comparison behaviors on distributive justice perception and job satisfaction. Social Behavior and Personality: An International Journal, 43(7), 1071-1083. https://doi.org/10.2224/sbp.2015.43.7.1071

Spector, P. E., \& Che, X. X. (2014). Re-examining citizenship: How the control of measurement artifacts affects observed relationships of organizational citizenship behavior and organizational variables. Human Performance, 27(2), 165-182 https://doi.org/10.1080/08959285.2014.882928

Su, F., Cheng, D., \& Wen, S. (2019). Multilevel impacts of transformational leadership on service quality: Evidence from china. Frontiers in Psychology, 1(10), 1252-1265. https://doi.org/10.3389/fpsyg.2019.01252

Sürücü, L., \& Maslakçı, A. (2020). Validity and reliability in quantitative research. Business \& Management Studies: An International Journal, 8(3), 2694-2726. https://doi.org/10.15295/bmij.v8i3.1540

Sürücü, L., \& Sağbaş, M. (2021). The impact of leadership styles on job satisfaction: A study of the $\begin{array}{llll}\text { hospitality industry. Yönetim Bilimleri Dergisi, 19(40), } & \text { 323-346. }\end{array}$ https://doi.org/10.35408/comuybd.787432

Taştan, M., \& Yılmaz, K. (2010). Örgütsel vatandaşlık ve örgütsel adalet ölçeklerinin Türkçeye uyarlanmas1. Eğitim ve Bilim, 33(150), 87-96. http://egitimvebilim.ted.org.tr/index.php/EB/article/view/633/103

Tian, H., Shuja Iqbal, S. A., Qalati, S. A., Anwar, F., \& Khan, M. A. S. (2020). The impact of transformational leadership on employee retention: Mediation and moderation through organizational citizenship behavior and communication. Frontiers in Psychology, 1(11). https://doi.org/10.3389/fpsyg.2020.00314

Van Knippenberg, D., De Cremer, D., \& Van Knippenberg, B. (2007), Leadership and fairness: The state of the art. European Journal of Work and Organizational Psychology, 16(2), 113-140. https://doi.org/10.1080/13594320701275833

Van Knippenberg, D., \& Sitkin, S. B. (2013). A critical assessment of charismatic-transformational leadership research: Back to the drawing board?. Academy of Management Annals, 7(1), 1-60. https://doi.org/10.5465/19416520.2013.759433

Wang, G., Oh, I. S., Courtright, S. H., \& Colbert, A. E. (2011). Transformational leadership and performance across criteria and levels: A meta-analytic review of 25 years of research. Group \& Organization Management, 36(2), 223-270. https://doi.org/10.1177/1059601111401017

Wisnawa, I. N. A., \& Dewi, A. S. K. (2020). Gaya kepemimpinan transformasional berpengaruh terhadap organizational citizenship behaviour dengan dimediasi variabel kepuasan Kerja. EJurnal Manajemen, 9(2), 528-552. https://doi.org/10.24843/EJMUNUD.2020.v09.i02.p07

Yıkılmaz, İ. (2020). Aile işletmelerinde dönüşümcü liderlik. O. Yılmaz, \& G. Bayramoğlu (Ed.), Aile ilişkileri bağlamında aile işletmeleri (ss. 59-78). Kriter Yayıncılık.

Zhang, H., Liu, Z., \& Wang, Y. (2020). How transformational leadership positively impacts organizational citizenship behavior in successful Chinese social work service organizations. Nonprofit Management and Leadership,30(3), 467-485. https://doi.org/10.1002/nml.21391 